\title{
Class C Orphans (version 2019.4) in the IUPHAR/BPS Guide to Pharmacology Database
}

Daniel Bikle ${ }^{1}$, Hans Bräuner-Osborne ${ }^{2}$, Edward M. Brown ${ }^{3}$, Arthur Conigrave $^{4}$ and Dolores Shoback ${ }^{1}$

1. University of California San Francisco, USA

2. University of Copenhagen, Denmark

3. Harvard University, USA

4. University of Sydney, Australia

\section{Abstract}

This set contains class C 'orphan' G protein coupled receptors where the endogenous ligand(s) is not known.

\section{Contents}

This is a citation summary for Class C Orphans in the Guide to Pharmacology database (GtoPdb). It exists purely as an adjunct to the database to facilitate the recognition of citations to and from the database by citation analyzers. Readers will almost certainly want to visit the relevant sections of the database which are given here under database links.

GtoPdb is an expert-driven guide to pharmacological targets and the substances that act on them. GtoPdb is a reference work which is most usefully represented as an on-line database. As in any publication this work should be appropriately cited, and the papers it cites should also be recognized. This document provides a citation for the relevant parts of the database, and also provides a reference list for the research cited by those parts.

Please note that the database version for the citations given in GtoPdb are to the most recent preceding version in which the family or its subfamilies and targets were substantially changed. The links below are to the current version. If you need to consult the cited version, rather than the most recent version, please contact the GtoPdb curators.

\section{Database links}

Class C Orphans

http://www.guidetopharmacology.org/GRAC/FamilyDisplayForward?familyld=18

Introduction to Class C Orphans

http://www.guidetopharmacology.org/GRAC/FamilyIntroductionForward?familyld=18

Receptors

GPR156

http://www.guidetopharmacology.org/GRAC/ObjectDisplayForward?objectld=209

GPR158

http://www.guidetopharmacology.org/GRAC/ObjectDisplayForward?objectld=210 


\section{GPR179}

http://www.guidetopharmacology.org/GRAC/ObjectDisplayForward?objectld=211 GPRC5A

http://www.guidetopharmacology.org/GRAC/ObjectDisplayForward?objectld=258 GPRC5B

http://www.guidetopharmacology.org/GRAC/ObjectDisplayForward?objectld=259 GPRC5C

http://www.guidetopharmacology.org/GRAC/ObjectDisplayForward?objectld=260 GPRC5D

http://www.guidetopharmacology.org/GRAC/ObjectDisplayForward?objectld=261 GPRC6 receptor

http://www.guidetopharmacology.org/GRAC/ObjectDisplayForward?objectld=55

\section{References}

1. Bräuner-Osborne H, Jensen AA, Sheppard PO, Brodin B, Krogsgaard-Larsen P and O'Hara P. (2001) Cloning and characterization of a human orphan family $C$ G-protein coupled receptor GPRC5D. Biochim Biophys Acta. 1518: 237-248 [PMID:11311935]

2. Bräuner-Osborne $H$ and Krogsgaard-Larsen P. (2000) Sequence and expression pattern of a novel human orphan G-protein-coupled receptor, GPRC5B, a family C receptor with a short amino-terminal domain. Genomics 65: 121-8 [PMID:10783259]

3. Cheng $Y$ and Lotan R. (1998) Molecular cloning and characterization of a novel retinoic acid-inducible gene that encodes a putative G protein-coupled receptor. J Biol Chem. 273: 35008-35015 [PMID:9446598]

4. Cool BH, Chan GC, Lee L, Oshima J, Martin GM and Hu Q. (2010) A flanking gene problem leads to the discovery of a Gprc5b splice variant predominantly expressed in C57BI/6J mouse brain and in maturing neurons. PLoS ONE 5: e10351 [PMID:20436672]

5. Deng J, Fujimoto J, Ye XF, Men TY, Van Pelt CS, Chen YL, Lin XF, Kadara H, Tao Q, Lotan D and Lotan

R. (2010) Knockout of the tumor suppressor gene Gprc5a in mice leads to NF-kappaB activation in airway epithelium and promotes lung inflammation and tumorigenesis. Cancer Prev Res (Phila) 3: 424-37 [PMID:20354164]

6. Faure H, Gorojankina T, Rice N, Dauban P, Dodd RH, Bräuner-Osborne H, Rognan D and Ruat M. (2009) Molecular determinants of non-competitive antagonist binding to the mouse GPRC6A receptor. Cell Calcium 46: 323-32 [PMID:19836834]

7. Inoue S, Sano H and Ohta M. (2000) Growth suppression of Escherichia coli by induction of expression of mammalian genes with transmembrane or ATPase domains. Biochem. Biophys. Res. Commun. 268: 553561 [PMID:10679242]

8. Jacobsen SE, Nørskov-Lauritsen L, Thomsen AR, Smajilovic S, Wellendorph P, Larsson NH, Lehmann A, Bhatia VK and Bräuner-Osborne H. (2013) Delineation of the GPRC6A receptor signaling pathways using a mammalian cell line stably expressing the receptor. J. Pharmacol. Exp. Ther. 347: 298-309 [PMID:24008333]

9. Kuang D, Yao Y, Lam J, Tsushima RG and Hampson DR. (2005) Cloning and characterization of a family C orphan G-protein coupled receptor. J. Neurochem. 93: 383-91 [PMID:15816861]

10. Peachey NS, Ray TA, Florijn R, Rowe LB, Sjoerdsma T, Contreras-Alcantara S, Baba K, Tosini G, Pozdeyev N and luvone PM et al.. (2012) GPR179 is required for depolarizing bipolar cell function and is mutated in autosomal-recessive complete congenital stationary night blindness. Am. J. Hum. Genet. 90: 331-9 [PMID:22325362]

11. Pi M, Faber P, Ekema G, Jackson PD, Ting A, Wang N, Fontilla-Poole M, Mays RW, Brunden KR and Harrington JJ et al.. (2005) Identification of a novel extracellular cation-sensing G-protein-coupled receptor. J. Biol. Chem. 280: 40201-9 [PMID:16199532]

12. Pi M, Wu Y and Quarles LD. (2011) GPRC6A mediates responses to osteocalcin in $\beta$-cells in vitro and pancreas in vivo. J. Bone Miner. Res. 26: 1680-3 [PMID:21425331] 
13. Pi M, Zhang L, Lei SF, Huang MZ, Zhu W, Zhang J, Shen H, Deng HW and Quarles LD. (2010) Impaired osteoblast function in GPRC6A null mice. J. Bone Miner. Res. 25: 1092-102 [PMID:19874200]

14. Robbins MJ, Michalovich D, Hill J, Calver AR, Medhurst AD, Gloger I, Sims M, Middlemiss DN and Pangalos MN. (2000) Molecular cloning and characterization of two novel retinoic acid-inducible orphan Gprotein-coupled receptors (GPRC5B and GPRC5C). Genomics 67: 8-18 [PMID:10945465]

15. Speca DJ, Lin DM, Sorensen PW, Isacoff EY, Ngai J and Dittman AH. (1999) Functional identification of a goldfish odorant receptor. Neuron 23: 487-98 [PMID:10433261]

16. Wellendorph $P$ and Bräuner-Osborne H. (2004) Molecular cloning, expression, and sequence analysis of GPRC6A, a novel family C G-protein-coupled receptor. Gene 335: 37-46 [PMID:15194188]

17. Wellendorph P, Burhenne N, Christiansen B, Walter B, Schmale H and Bräuner-Osborne H. (2007) The rat GPRC6A: cloning and characterization. Gene 396: 257-67 [PMID:17478059]

18. Wellendorph P, Hansen KB, Balsgaard A, Greenwood JR, Egebjerg J and Bräuner-Osborne H. (2005) Deorphanization of GPRC6A: a promiscuous L-alpha-amino acid receptor with preference for basic amino acids. Mol. Pharmacol. 67: 589-97 [PMID:15576628]

19. Xu J, Tian J and Shapiro SD. (2005) Normal lung development in RAIG1-deficient mice despite unique lung epithelium-specific expression. Am J Respir Cell Mol Bio/32: 381-387 [PMID:15677768]

20. Ye X, Tao Q, Wang Y, Cheng Y and Lotan R. (2009) Mechanisms underlying the induction of the putative human tumor suppressor GPRC5A by retinoic acid. Cancer Biol. Ther. 8: 951-62 [PMID:19279407] 